\title{
DISEASE-RELATED NEEDS OF BLACK PATIENTS WITH CERVICAL CANCER
}

\author{
Ina Treadwell
}

\section{Abstract}

The high incidence of cenvical cancer amongst South African black women is complicated by late presentation for treatment as well as by misconceptions and ignorance which adversely affect the quality of their lives. The aim of the research was to determine the disease-related needs of patients suffering from cervical cancer which would serve as a basis for planning on providing for these needs.

Needs for the following were identified:

- Education on early detection in the community.

- Education on nutrition and hygiene.

- Information on and assistance in obtaining financial relief by means of subsidised transport and disability pensions.

Opsomning

Die hoë insidensie van servikale karsinoom onder swart vroue in Suid-Afrika word gekompliseer deur aanmelding vir mediese behandeling op 'n gevorderde stadium van die siekte sowel as deur wanopvattings en gebrekkige kennis wat die kwaliteit van hul lewens nadelig beïnloed.

Die doel van die studie was om die behofftes van servikale karsoom pasiënte te identifiseer sodat beplan kan word hoe om in die behoeftes te voorsien.

Behoefte aan die volgende is geidentifiseer:

- Inligting aan die gemeenskap oor die vroeë opsporing van karsinoom

- Inligting aan pasiënte na ontslag oor voeding en higiëne

- Inligting oor en steun in die verkryging van finansiële bystand in die vorm van ongeskiktheidspensioen en reistoelae.

\section{INTROIUCTION}

Slatistics kept by the oncology nurses at the Ga-kankuwa Hospital revealed that cancer of the cervix comprised $30 \%$ of the total of 962 cancers treated at the hospital in 1986. 'This high incidence concurs with findings published in the 1986 Cancer Registry of South Africa according to which cervical cancer accounted for $43 \%$ of all specific incident cancers amongst a total of 2274 black women

'This high incidence is aggravated by the fact that blacks suffering from cervical cancer who seek help at a hospital often have cancer in an advanced and incurable stage with resultant poor survival rates. Such late presentation is very costly - not only in terms of human lives but also financially. These patients are hospitalised for five weeks to receive chemoand radiotherapy. The hospitalisation costs alone amount to $\mathrm{R} 4130$ per patient if calculated at a figure of R118 per day as quoted by a hospital administrator in 1988.

Oncology nurses from the Ga-Rankuwa llospital reported to the researcher that apart from having a poor prognosis the diagnosed patients' suffering is often aggravated by ignorance and misconceptions which adversely affect the quality of their lives. This study was aimed at identifying these patients' needs for information on disease-related matters which could be provided by health professionals.

\section{PROBLEM STATEMENT}

The high prevalence of cervical cancer amongst black South African women is complicated by late presentation for treatment as well as by misconceptions and ignorance which adversely affect the quality of their lives.

\section{AIM}

The aim of the research was to determine the disease-related needs of hospitalised black patients suffering from cervical cancer which would serve as a basis for planning in order to meet these needs.

\section{OBJECTIVES}

To do a survey of hospitalised black patients suffering from cervical cancer in order to determine

- demographic data pertaining to the respondents

- the stage of their disease on admission

- the possible reasons for late presentation for treatment

- the physical problems experienced

- the beliefs about the sequelac of their discase

- suppor from other patients suffering from cervical cancer

- the input from health professionals regarding consultation and discussion of the disease

It was hoped that clarification of the above variables would allow recommendation of nursing measures to help meet needs thus identified.

\section{LI'TERA'TURE STUDY}

Cervical cancer is characterized by a long, asymptomatic premalignant phase, during which it can be detected only by means of cervical cytology. Farly detection is desirable for reduction in the mortality rate since eradication of this pre-malignant lesion is associated with $100 \%$ curability. Cervical cancer can therefore be described as a 
potentially preventable neoplasm (Kahn et al., 1987:89).

The control of cervical cancer in many countries is impressive and the prevalence low. In the United Kingdom, for instance, cervical cancer comprises only $4.3 \%$ of all incident cancers (Buicher, 1987:7). The corresponding figure for black women in 1986 was an alarming 43\% (Cancer registery of South Africa 1986). Presentation for treatment is also at a later stage than in whites, which results in poorer survival and cure rates (Kahn et al., 1987:89).

Gordon Grant ascribes the fact that cervical carcinoma has been reduced to a minor problem in other countries to the mass screening of cerlain age groups and propaganda disseminated via the press, radio and television. Mass prophylaxis in South Africa poses a problem since free Papanicolaou (Pap) smears at state family planning clinics have been curbed since 1975 (Gordon Grant, 1982:821).

A study done amongst Johannesburg women on their knowledge of and attitudes toward cancer of the cervix revealed although only $27 \%$ of the black women had cervical smears taken, $83 \%$ indicated a willingness to have a free Pap smear done after the significance was explained to them. Although $72 \%$ of the black patients indicated a desire for further information only $33 \%$ had asked their doctors for information on their disease (Kahn et al., 1987:91).

It is important to note that although the level of knowledge of a common cancer and its prevention was found to be markedly deficient amongst black women, they indicated a willingness and readiness to participate in preventive as well as therapeutic measures once they have been informed of the nature of the disease (Kahn et al, 1987:92). On the other hand they are reluctant to undergo hysterectomy since, according to black culture, a woman is considered to be less valuable in marriage, even divorcable, if she can no longer bear children (Kahnet al, 1987:92). Ill health concerning the reproductive system therefore strikes at the core of African lifestyles and beliefs. It has so many socio-cultural implications that the opportunity for early diagnosis and treatment is negated (Searle, 1986:7).

Traditional healers have an entrenched relationship with their community (Searle, 1986:6) and are usually the first to be consulted when health problems occur. Western doctors are the second choice and this phenomenon leads to patients secking Westem health care at a latc stage and with a poor prognosis (Van Rensburg, 1981:42).

The psychological impact of cancer is often devastating and therefore treatment aimed at stress reduction and emotional support should be an integral part of the management of patients with cancer pain (Warfield, 1987:101). Most patients want to discuss their problems with not

NUMBER OF

\section{RESPONDENTS}

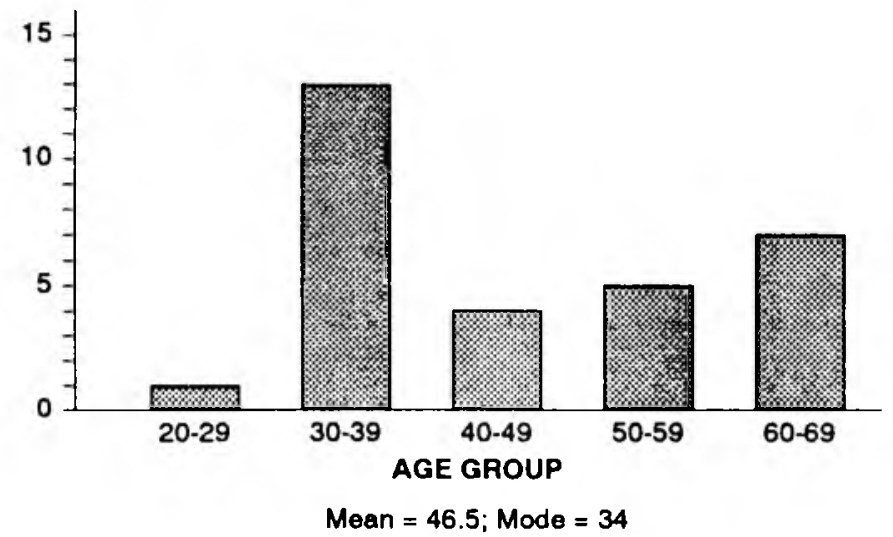

Figure 1

Age on Admission $(n=30)$

only health professionals but also with other patients who have undergone a similar experience (Ariel and Cleary, 1987:534).

Findings therefore indicate a failure in primary health education as well as a need for more explanation to women attending clinics and to patients undergoing therapy (Kahn et al., 1987:92).

\section{METIIOD}

A questionnaire was compiled to obtain information on the respondent's stage of disease on admission, reasons for late presentation, physical problems, beliefs, support and input from health professionals. The instrument was tested for face validity and pilot tested by interviewing five patients.

In order to overcome language problems the questionnaires were completed by black professional nurses who had been briefed beforehand. These nurses were lecturers in the Nursing Science Department and a B Cur (I et A) student at Medunsa as well as an oncology nurse at the Ga-Rankuwa Hospital.

The convenience sample for this descriptive survey comprised thirty hospitalised patients suffering from cancer of the cervix. The respondents received radio- and chemotherapy and were in different stages of their five week hospitalisation period. Permission was obtained for each interview which lasted approximately twenty minutes. Due to the busy schedules of the fieldworkers, the patients selected were all those who were in the wards at times convenient for the fieldworkers. The study was carried out during the period December 1987 to March 1988.

Responses to the questionnaires were computer-analysed by the Department of
Biostatistics of the Medical Research Council.

\section{RESULTS}

\section{Demographic data}

- The peak incidence of cervical carcinoma (Fig.1) was in the $\mathbf{3 0}$ to 39 year age group with a mean of 34 years. This is at least 10 years younger than findings of internation: studies (Angell \& Riche, 1981:568)

- All the patients had children, the number ranging from 2 to 13. A though the mean number was 5,1 the majority $(63 \%)$ of the sample had 2 to 4 children.

* The average annual income per family was low (R5 132).

Unfortunately the number of dependants per family is not known.

\section{Stage of cancer on admission}

It was found that the majority of the respondents $(83,3 \%)$ had cancer in an advanced stage i.e. Stages 2 and 3 on admission (Fig. 2). Surgery was performed on only $6,7 \%$ of the respondents.

Possible reasons for late presentation for treatment

- The main reasons given for seeking medical help (Table 1) were vaginal discharge, bleeding and pain, the latter being a very late symptom. None of these patients had ever had a PAP smear taken as routine checkup.

- When asked to list the warning signs of cancer (Table 2) all the respondents obviously knew by then what vaginal bleeding and/or discharge meant. The second and third best-known signs were a lump in the breast and 
TABLE 1

REASONS FOR SEEKING MEDICAL HELP $(n=30)$

\begin{tabular}{|l|c|c|}
\hline \multicolumn{1}{|c|}{ REASONS } & FREQUENCY & $\boldsymbol{\chi}$ \\
\hline Vaginal discharge & 25 & 83,3 \\
\hline Vaginal bleoding & 23 & 76,7 \\
\hline Pain & 15 & 50,0 \\
\hline
\end{tabular}

TABLE 2

KNOWLEDGE OF WARNING SIGNS $(n=30)$

\begin{tabular}{|l|c|c|}
\hline \multicolumn{1}{|c|}{ WARNING SIGNS } & FREOUENCY & $\boldsymbol{*}$ \\
\hline Unusual bleeding or discharge & 30 & 100,0 \\
\hline Lump in breast or elsewhere & 22 & 73,3 \\
\hline Indigestion or difficulty in swallowing & 6 & 20,0 \\
\hline Nagging cough or hoarseness & 3 & 10,0 \\
\hline Change in wart or mole & 2 & 6,7 \\
\hline Change in bowel or bladder habits & 1 & 3,3 \\
\hline A sore that does not heal & 0 & 0 \\
\hline
\end{tabular}

TABLE 3

RESPONDENTS' BELIEFS ABOUT THE SEQUELAE OF THEIR DISEASE

\begin{tabular}{|l|c|c|}
\hline \multicolumn{1}{|c|}{ BELIEF } & FREOUENCY & $\boldsymbol{*}$ \\
\hline Coitus will be painful & 19 & 63,3 \\
\hline Will bleed after coitus & 16 & 53,3 \\
\hline Husband will reject her & 15 & 50,0 \\
\hline Will not be able to have intercourse & 13 & 43,3 \\
\hline Will loose sexuality & 10 & 33,3 \\
\hline If menses stops, blood will go to head & 3 & 10,0 \\
\hline
\end{tabular}

\section{NUMBER OF}

RESPONDENTS

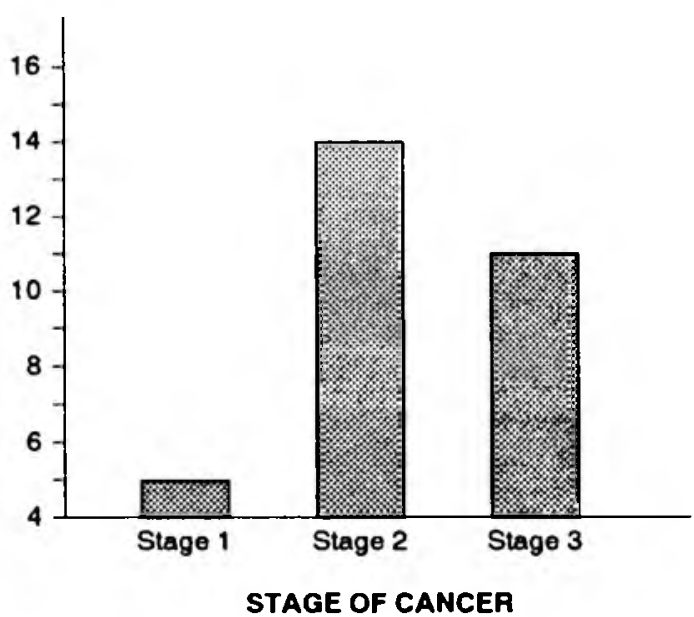

Figure 2

Stage of Cancer on Admission

indigestion/dysphagia. These three warning signs are indicative of the three most prevalent cancers seen at the Ga-Rankuwa hospital. Knowledge of the other warning signs was very poor.
Physical problems experienced

- Ineffective pain control was experienced by only one respondent. Paracetamol and/or Mist TC (Morphine mixture) was taken by the majority of respondents at an average frequency of 9 to 12 hourly.

* The main physical problems experienced (Fig.3) were associated with the gastro-intestinal tract namely constipation, weight loss, nausea, vomiting and anorexia. The occurence of these problems was at least 3 times more frequent than any other problem.

- Other problems included foul-smelling discharge (50\%) and urinary tract infection (13\%).

\section{Beliefs about sequelae of disease}

Most of these beliefs were centered around marital relations (Table 3).

\section{Support groups}

In hospital $30 \%$ of the patients were supported by others suffering from cervical cancer

\section{Input of health workers}

A comparison of the availability and input of health care workers regarding consultation and discussion of the disease appear in Fig. 4 :

- As can be expected the doctor had the greatest input.

- The clinic nurse, available to $90 \%$ of the respondents, was only consulted by $3 \%$ of the respondents before hospitalisation

- Social workers made almost no input $(6,7 \%)$ although they were available to $60 \%$ of the respondents.

- The traditional healer was available to $97 \%$ of the respondents.

- Although traditional healers discussed cancer with only $3 \%$ of the respondents (Fig. 4), $46,7 \%$ visited and took medicine prescribed by a traditional healer. The mean number of such visits was 1,3 .

Media for health education

- Mass media are available to most respondents but seems to be underutilised (Fig.5):

Seventy-seven percent of the respondents were literate but only $23 \%$ had seen literature in the form of brochures on cancer.

All the respondents listen to the radio frequently but no regular cancer-education programmes on cancer are being broadcast.

- A telephone is available to all but 3,3\% (Fig.6).

\section{CONCLUSIONS}

From the data analysis the following needs were identified:- 


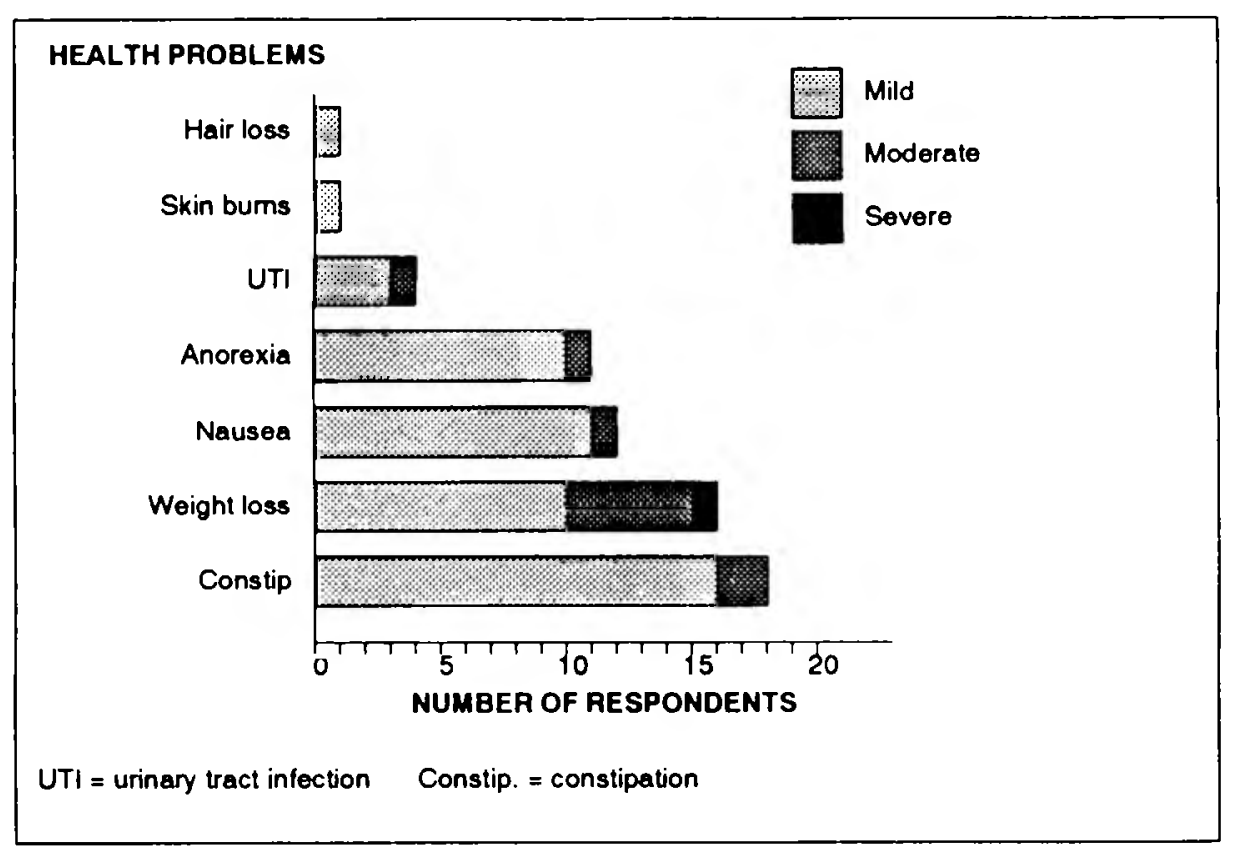

Figure 3

Health Problems

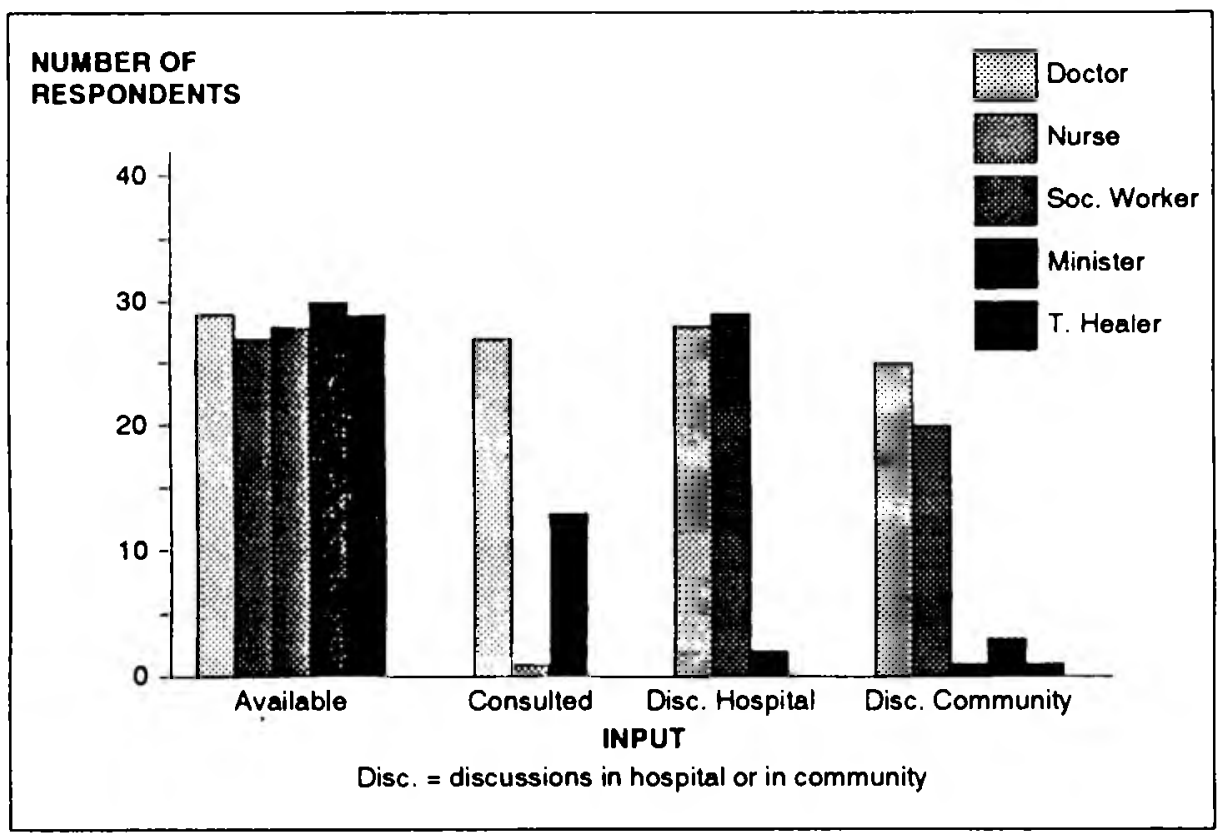

Figure 4

Input of Health Workers

- Health education to the public on early detection of cancer

- Motivation for regular checkups and PAP smears

- Education of patients suffering from cervical cancer on:

- nutrition as the occurence of problems associated with the gastro-intestinal tract was at least 3 times more frequent than any other problem.

- hygiene since it could alleviate the foul-smelling discharge and urinary tract infection experienced in African culture and is readily available.

- mass media are available to the majority of respondents but are underutilised for cducational purposes.

- a telephone is available to all but $3,3 \%$ which implies that counselling and referrals in some instances could be done without the inconvenience and cost of travelling.

\section{RECOMMENDATIONS}

In the light of the findings nurses could undertake the following actions to meet the identified needs of cervical cancer patients:-

\section{Health education to the public}

- The importance of early detection and treatment should be emphazised. Printed information on warning signs of cancer is available from the National Cancer Association. These are easily obtained and can be distributed and further explained at clinics.

- Education on cancer prevention and detection through the mass media should be encouraged since all the respondents listen to the radio and most ( $77 \%$ ) are literate.

- Health education should not only be given but also critically evaluated by testing the comprehension of the public (McInemey 1988:28).

Motivate women over the age of 25 years to have a Pap smear taken annually.

Unfortunately a national screening programme in South Africa does not exist although it has been advocated since 1982 as an urgent priority in order to reduce the enormous cost of treatment of an advanced malignant discase which potentially is preventable (Gordon Grant, 1982:821). Since the scope of nursing practice includes physical assessments and Pap smears the question arises as to reasons why existing clinic facilities cannot be extended to provide for cancer screening.

Nurses should be involved in the planning and implemention of such a programme (Mclnerney, 1988:29). respondents reponed hat their pain was effectively controlled one must bear in mind that black patients have a different perspective on pain and do not complain casily.

- Guidance by social workers to help alleviate the financial implications of the disease.

- Counselling and information on what to expect of marital relations since uncertainty gives rise to misconceptions and anxiety.

- The data revealed resources which could be utilised to meel the discase related needs:

- the traditional healer still plays a major role
Education of patients

Patients who experience health problems as reported above should be guided on nutrition and hygiene. Patients may be counselled to rule out misconceptions about their discase.

Initiate support groups made up of women suffering from cervical cancer.

Patients can be referred to their nearest clinic after being discharged and group meetings/visits can be arranged or co-ordinated by the clinic sister or a contact person. 


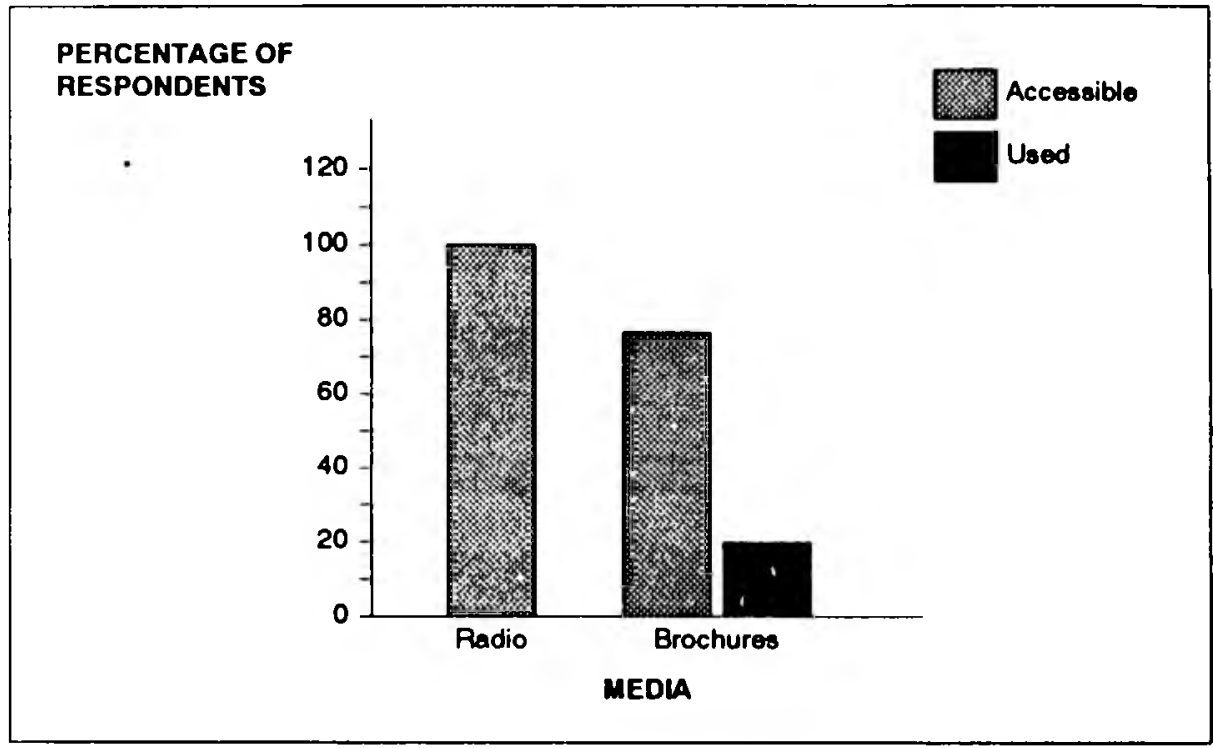

Figure 5

Mass Media for Health Education

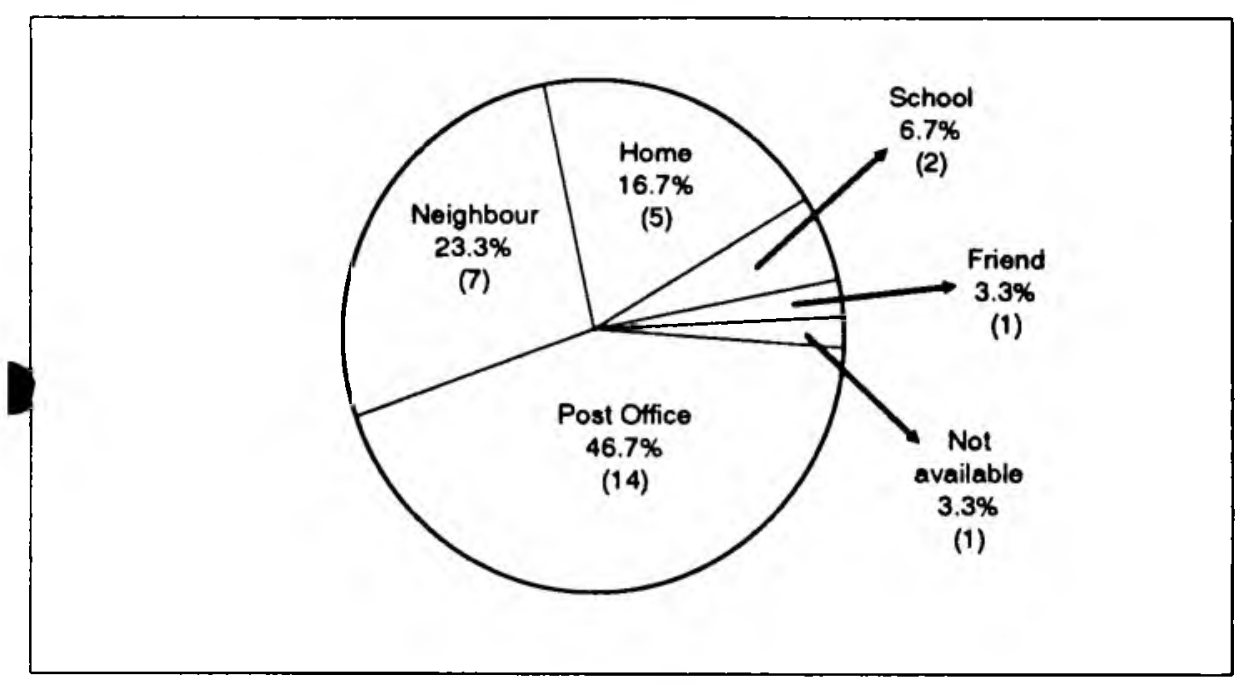

Figure 6

Availability of Telephone

Nurses have the responsibility to refer patients to social workers who are able to play an active role in alleviating social and financial problems related to travel subsidies and disability pensions.

Such advice may relieve the financial burden caused by the disease Nurses should verify whether patients are aware of and know how to
Telephone Information Service.

A telephone information service should be initiated in order to counsel and refer patients which could in some instances prevent the inconvenience and cost of travelling

\section{BIBLIOGRAPHY}

ANGELL, M.A. AND RIGHE, J.R. 1981. Basic Pathology. Toronto: W B Saunders.

ARIEL, I.M. AND CLEARY, J.B. 1987 Breast Cancer. New York: McGraw-Hill.

BUTCHER, J. (Ed.) 1987. Breaking the silence on cancer. London: BACUP

CANCER REGISTRY OF SOUTH AFRICA. 1986. Johannesburg: SAIMR

GORDON GRANT, M.C. 1982. Carcinoma of the cervix - a tragic disease in South Africa. Sourh African MedicalJournal, 61:819-822.

McINERNEY, P. 1988. Cervical intraepithelial neoplasia - its prevention and the role of the nurse. Nursing RSA, 3(2), 26-29.

KAHN, H., BERELOWITZ, L., BORODA, A., CHIMES, M., GARDNER, S., GORDON, B., MANOIM, T., MIRMAN, R., SMITH, R., AND LEIMAN, G. 1987. Knowledge of and attitudes toward cancer of the cervix in Johannesburg women. The Southern African Journal of Epidemiology and Infection. 3:89-92.

SEARLE, C. The problem of establishing early detection programmes in developing countries. Nursing RSA, 1(10). November 1986:4.

VAN RENSBURG, H.C.J. Die aard en die tradisionele, nie-Westerse of stammedisyne in Suid-Afrika. Curationis, 4(2), September 1981.

WARFIELD, C.A. Pharmacologic Treatment of Cancer Pain. Hospital Practice, October 1987:93.

apply for disability pensions and subsidised transport. Co-operation with traditional healers might
be obtained.

If they were given information on health education and cancer prevention they could serve as a valuable source of information to their clients.
Ina Treadwell

D.CUR, R.N., R.M., R.N.A., R.C.N., Intensive Care.

MEDUNSA - Department of Nursing Science 